\title{
The Effect of Chlorination on Escherichia Coli Viability in Drinking Water
}

\author{
Viktorija Denisova ${ }^{1}$, Linda Mezule ${ }^{2}$, Talis Juhna ${ }^{3}$, \\ ${ }^{1-3}$ Riga Technical University
}

\begin{abstract}
The assessment of drinking water disinfection efficiency traditionally involves the estimation of faecal indicator inactivation rates in the form of reduction of cultivable counts. Widely described, viable but noncultivable (VBNC) state as a form of bacterial survival strategy in oligotrophic conditions is not considered in these estimations. The aim of the present research is to assess the effect of free chlorine disinfection on faecal indicator Escherichia coli in order to study the succession of cellular alterations in response to chlorine exposure. To determine the inactivation rates, cell ability to form colonies, ability to divide as such and metabolic activity have studied. $0.064 \mathrm{mg} / \mathrm{L} \mathrm{min}{ }^{-1}$ free chlorine has been needed to obtain $99 \%$ inactivation of cultivable counts; however, 5 till 200 times higher disinfectant dose $x$ contact time has been required to reduce cell ability to divide and metabolic activity, respectively. The results have shown that to determine correct drinking water disinfectant doses multiple cell viability parameters should be analyzed.
\end{abstract}

Keywords - Chlorination, Escherichia coli, inactivation kinetic, viability.

\section{INTRODUCTION}

In drinking water treatment, disinfectant doses and subsequent disinfection kinetics are determined by using the concept of residual disinfectant concentration multiplied by contact time (CT) [1]. The kinetics of $E$. coli inactivation is usually described by Chick-Watson first order equation, and it uses the data obtained from plate counts, where accurate enumeration is of high importance to assess microbiological water quality [2]. However, many pathogens like Giardia [3] and Cryptosporidium [4] are resistant to the disinfection doses currently applied for drinking water. Moreover, an additional protection to microorganisms can be attained by their attachment to the biofilms [5].

It is accepted that the detection of $E$. coli in the water indicates the presence of possibility of waterborne pathogens with a subsequent risk to public health. For preparation of drinking water, including disinfection processes, at the moment all engineering calculations are based only on microbial ability to form colonies. However, many bacteria, including pathogenic $E$. coli, when subjected to stress may be present in the drinking water in a noncultivable state often referred to as viable but noncultivable (VBNC) state. It is assumed that bacteria in the VBNC state fail to grow on routine bacteriological media, on which they would normally grow and develop into colonies, but are alive and capable of renewed metabolic activity [6]. Nevertheless, it has been shown that in this state, bacteria are able to retain their pathogenicity [7] and even resuscitate [8]. Therefore, to assess the disinfection kinetics of waterborne microorganisms not only cultivable but all viable cells should be evaluated. Since the VBNC concept still requires some clarification, viability markers (membrane integrity, enzymatic activity etc.) are the most appropriate [9], the detection of at least two would be recommendable.

In this study, with traditional culture based assays, two viability techniques - cell ability to divide (direct viable count, DVC) [10] and respiratory activity (CTC assay) [11] were used to assess the effect of chlorine disinfection to neutralize E. coli in the drinking water. The DVC technique involving the incubation of the samples with nutrients and an antibiotic (nalidixic acid) allows detecting all cells having any potential for dividing, but not exclusively to form colonies on a solid culture medium. Limited ability to divide can be linked to the exposure to stress [12], however, is not a restricting potential to form toxic substrates [6]. Cell respiratory activity measurements in the form of introduction of an artificial electron acceptor (CTC) were selected due to their robustness (formation of insoluble crystals visible by fluorescence microscopy) and simultaneous toxicity of formed formazan crystals [13], thus, excluding cell division during sample treatment. Moreover, the method was chosen as a marker for a metabolic activity with no connection to cell multiplication.

To reflect the chlorine inactivation kinetics on E. coli, two reagent based disinfection techniques were used in this study chemical chlorination (addition of hypochlorite) as active disinfectant and electrochemical disinfection, where active disinfectant was generated from salt ions naturally found in water. Electrochemical approach was chosen because of its ability to constantly generate low amounts of active disinfectant over a period of time, thus, providing longer contact time.

\section{MATERIALS AND METHODS}

\section{A. Bacterial Strains and Culture Conditions}

E. coli ATCC ${ }^{2} 25922$ was inoculated in sterile tryptone soya broth (TSB, Oxoid Ltd, UK) and cultivated at $37{ }^{\circ} \mathrm{C}$ with constant shaking at $200 \mathrm{rpm}$. Then $E$. coli cells were centrifuged in a microtube at $2000 \mathrm{~g}$ for 2 minutes (Minispin, Eppendorf) and rinsed with sterile distilled water. The centrifuging and rinsing processes were conducted thrice to completely remove the culture medium. The final bacterial pellet was re-suspended in sterile phosphate buffered saline (PBS, $7 \mathrm{mM}$ $\mathrm{Na}_{2} \mathrm{HPO}_{4}, 3 \mathrm{mM} \mathrm{NaH} \mathrm{PO}_{4}, 130 \mathrm{mM} \mathrm{NaCl}, \mathrm{pH}$ 7.2) to obtain a stock solution of E. coli $\left(\sim 10^{7} \mathrm{CFU} \mathrm{mL} \mathrm{mL}^{-1}\right)$.

In order to determine the exact cell concentration $0.005 \mathrm{~mL}$ of the stock suspension was filtered through a sterilized $25-\mathrm{mm}$ diameter $0.2-\mu \mathrm{m}$-pore-size filter (Sartorius, Polycarbonate 
Track- Etch Membrane, Germany) and fixed with $3 \%-4 \%$ formaldehyde for 10 minutes, washed with sterile distilled water and stained with $10 \mu \mathrm{g} / \mathrm{mL}$ DAPI (4',6-diamidino-2phenylindole, Merck, Germany) for 5-10 minutes. Cell concentration was determined with epifluorescence microscopy (Ex: 340/380; Em: > 425, dichromatic mirror $565 \mathrm{~nm}$, Leica DMLB, Germany) by counting of 20 random fields of view.

\section{B. Disinfection Experiments}

\section{Chlorination}

Batch scale experiments were performed in well-mixed $250 \mathrm{~mL}$ Erlenmeyer glass flasks containing $100 \mathrm{~mL}$ sterile, prefiltered phosphate buffer solution $\left(0.039 \mathrm{M} \mathrm{NaH} \mathrm{PO}_{4}\right.$, $0.061 \mathrm{M} \mathrm{Na}_{2} \mathrm{HPO}_{4}, \mathrm{pH}$ 7.0). The flasks were mixed with constant shaking (Biosan, Latvia) at $150 \mathrm{rpm}$ at room temperature $25 \pm 2{ }^{\circ} \mathrm{C}$. First, different sodium hypochlorite chlorine doses were added $(0.05 \mathrm{mg} / \mathrm{L}, 0.1 \mathrm{mg} / \mathrm{L}, 0.2 \mathrm{mg} / \mathrm{L}$, $0.5 \mathrm{mg} / \mathrm{L}$ and $5 \mathrm{mg} / \mathrm{L}$ as free chlorine), which were prepared by diluting commercially available sodium hypochlorite $(\mathrm{NaClO}$, VWR International Ltd., Poole, BH15 1TD, England) in sterile distilled water, and the free chlorine concentrations were determined using the N, N-diethyl-p-phenylenediamine (DPD) colorimetric method, according to the procedure described by LVS EN ISO 7393-1:2001 [14]. In this method, the DPD was oxidized by free chlorine, resulting in a solution with color intensity proportional to the free chlorine concentration. Then a known concentration of $E$. coli cells was added to $100 \mathrm{~mL}$ sterile, pre-filtered $0.2 \mathrm{M}$ phosphate buffer solution containing a known concentration of chlorine. After inoculation (final concentration $1 \times 10^{6} \mathrm{E}$. coli cells $\left.\mathrm{mL}^{-1}\right)$, inactivation kinetics was studied for $1 \mathrm{~h}$ (0.5 min., $1 \mathrm{~min} ., 5 \mathrm{~min}$., $10 \mathrm{~min}$., $30 \mathrm{~min}$., 60 minutes). Immediately after the sampling, residual chlorine was neutralized with equal or excess volume of $0.02 \mathrm{M}$ sodium thiosulfate $\left(\mathrm{Na}_{2} \mathrm{~S}_{2} \mathrm{O}_{3}\right)$. Each experiment was performed in triplicate. All the results were expressed in milligrams of chlorine as $\mathrm{Cl}_{2}$ per liter.

\section{Electrochemical Disinfection}

To $0.5 \mathrm{~L}$ of sterile synthetic $E$. coli free water $(0.039 \mathrm{M}$ $\mathrm{NaH}_{2} \mathrm{PO}_{4}, 0.061 \mathrm{M} \mathrm{Na}_{2} \mathrm{HPO}_{4}, 1 \mathrm{mM} \mathrm{KCl}, \mathrm{pH}$ 7.0) E. coli with a final concentration of $1 \times 10^{6} / \mathrm{mL}$ was added. Electrochemical treatment of the samples was performed in a specially made electrolytic cell consisting of pure $\mathrm{TiO}_{2-x}$ ceramic anode [15] with an area of $12.1 \mathrm{~cm}^{2}$ and a cathode made of stainless steel (AISI 304), with a total surface area of $18 \mathrm{~cm}^{2}$. The cathode consisted of two identical plates placed in parallel on either side of the anode, $5 \mathrm{~mm}$ away from it [16]. Power to the electrochemical reactor was supplied by HQ Power, PS5005 $(0-50 \mathrm{~V}$ DC, $0-5 \mathrm{~A}$, direct current rectifier). Standard electrolysis process was carried out at current intensity of $0.1 \mathrm{~A}$, $23{ }^{\circ} \mathrm{C} \pm 2{ }^{\circ} \mathrm{C}$ with intensive stirring. Samples were collected before electrolysis $(0 \mathrm{~h})$ and after $5 \mathrm{~min}, 15 \mathrm{~min}, 30 \mathrm{~min}$ and 120 minutes of treatment. Immediately after the sampling, residual chlorine was neutralized with equal or excess volume of $0.02 \mathrm{M}$ sodium thiosulfate $\left(\mathrm{Na}_{2} \mathrm{~S}_{2} \mathrm{O}_{3}\right)$. Each experiment was performed in triplicate.

\section{Cultivable Cell Counts}

Cultivable E. coli was estimated with the plate count technique: $0.1 \mathrm{~mL}$ aliquot of the sample or its decimal dilution was inoculated on TBX agar (Oxoid Ltd., UK) and incubated for 24 hours at $37^{\circ} \mathrm{C}$. Each sample was plated in triplicate. The results were expressed as colony forming units (CFU) per milliliter.

\section{Direct Viable Count}

Cell potential for dividing was determined by modified direct viable count (DVC) method [10] and combined with DAPI staining. In brief, samples were incubated in double diluted tryptone soya broth (Oxoid Ltd) and $10 \mu \mathrm{g} / \mathrm{mL}$ nalidixic acid for 6 hours at $30{ }^{\circ} \mathrm{C}$ on an orbital shaker at $200 \mathrm{rpm}$ (Biosan, Latvia). After incubation the samples were fixed with $3 \%-4 \%$ (final concentration) formaldehyde solution for 10 minutes. Then the samples were filtered through a 25-mm-diameter $0.2-\mu \mathrm{m}$-pore-size filter (Anodisc, Whatman International Ltd., Germany), rinsed with $100 \mathrm{~mL}$ of sterile distilled water and stained with $10 \mu \mathrm{g} / \mathrm{mL}$ DAPI for 15 minutes. After staining, the samples were rinsed with sterile distilled water and air-dried.

For data analyses at least 20 microscope images were made (Ex: 340/380; Em: > 425, dichromatic mirror 565 nm, Leica DMLB, Germany) and 300 randomly chosen cells lengths $(\mu \mathrm{m})$ were measured with Image Pro Plus 4.5.1 software. Cells were set as elongated if they were $\geq 1.5$ times longer than their original length (no DVC treatment).

\section{E. Metabolic Activity Measurements}

The samples were incubated in equal amount of Luria-Bertrani (LB) broth (tryptone $-10 \mathrm{~g} / \mathrm{l}$, yeast extract $-5 \mathrm{~g} / \mathrm{l}, \mathrm{NaCl}-10 \mathrm{~g} / \mathrm{l}$ ) and $4 \mathrm{mM}$ final concentration of CTC (5-cyano-2,3-ditolyl tetrazolium chloride, Fluka, BioChemika) for 2 hours in the dark at room temperature on an orbital shaker (200 rpm). Then the samples were filtered through a 25-mm-diameter 0.2- $\mu \mathrm{m}$-pore-size filter (Anodisc, Whatman International Ltd., Germany), fixed with $3 \%-4 \%$ formaldehyde, rinsed with sterile distilled water and stained with $10 \mu \mathrm{g} / \mathrm{mL}$ DAPI for 15 minutes. Actively respiring and non-respiring cell numbers were determined with epifluorescence microscopy (Leica DM LB, Germany) for DAPI (Ex: 340/380; Em: > 425) and for red fluorescent CTC-formazan crystals (Ex: $545 \mathrm{~nm} \pm 30 \mathrm{~nm}$; Em: $610 \mathrm{~nm} \pm 75 \mathrm{~nm}$ ). Metabolically active cells were determined by counting 60 random fields of view, giving a detection limit of 174 cells per $\mathrm{mL}$.

\section{F. Disinfection Kinetics}

The effectiveness of disinfection process is obtained using the concept of residual disinfectant concentration multiplied by contact time or CT [17]. The kinetics of E. coli inactivation is usually described by Chick-Watson first order equation:

$$
\log \left(N / N_{0}\right)=-k C^{n} T
$$

where $N / N_{0}$ is the ratio of survived $E$. coli at time $t, N$ is the concentration of viable $E$. coli exposure to a disinfectant, $N_{O}$ is the initial concentration of viable E. coli, $C$ is the residual disinfectant concentration in $\mathrm{mg} / \mathrm{L}$, and $k$ and $n$ are empirical 
constants $(n=1), \mathrm{T}$ is the contact time in minutes when residual disinfectant is in contact with the water [18]. CT concept is used by public supply systems as one tool for ensuring adequate inactivation of organisms during disinfection [19]. Basically, $\log$ inactivation is expressed as the number or percent of microorganisms inactivated (killed or unable to replicate) through the disinfection process. It means that $1-\log$ inactivation value is equivalent to $90 \%$ of microorganisms reduction, 2-log is $99 \%$ reduction, 3- $\log$ is $99.9 \%$ reduction, $4-\log$ is $99.99 \%$ reduction, and so on [20].

\section{G. Statistical Analysis}

Statistical analyses were performed in MS Excel using Data analysis ANOVA tool or T-test to compare data sets. The level of significance was set at $P<0.05$ for all comparisons.

\section{RESULTS}

The inactivation effect of electrochemical disinfection and chlorination using sodium hypochlorite solution $(\mathrm{NaOCl})$ on $E$. coli was investigated. Three different methods (CFU count, the number of DVC-elongated cells, the number of CTC-positive cells) were used for $E$. coli detection in the drinking water after chlorination and electrochemical disinfection.

\section{A. Chlorination}

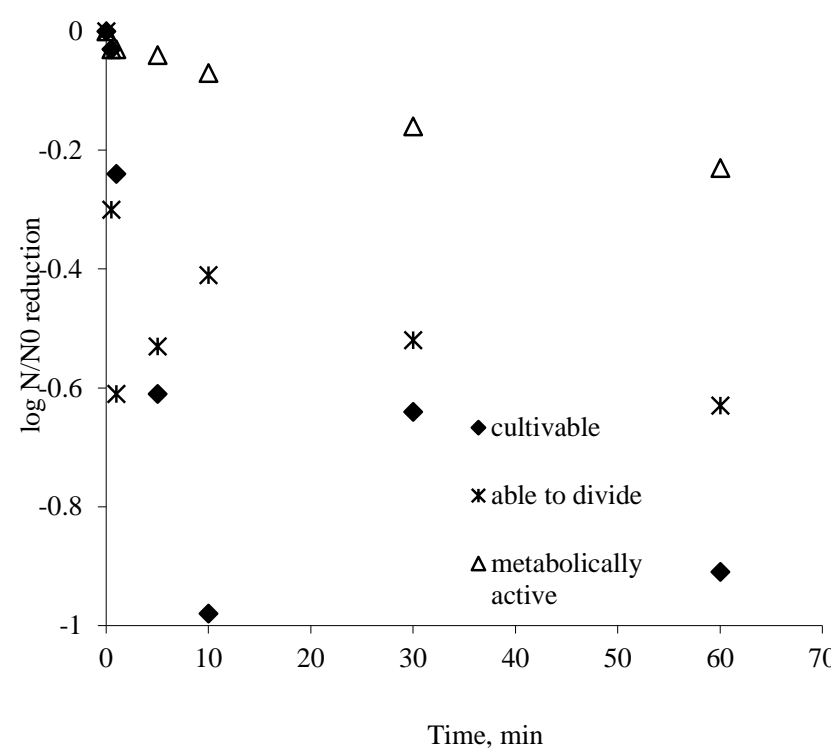

Fig. 1. Effect of $0.05 \mathrm{mg} / \mathrm{L}$ chlorine concentration on inactivation of cultivable $(\bullet)$, able to divide $(\times)$ and metabolically active $(\Delta) E$. coli. The data are the mean of three separate experiments.

The results showed (Fig. 1) that at a low initial chlorine concentration $\left(0.05 \mathrm{mg} / \mathrm{L}\right.$ as $\left.\mathrm{Cl}_{2}\right)$, the number of able to divide E. coli cells decreased by $0.63-\log$ after 1 hour. At the same time, a higher decrease was observed for cultivable counts (0.91-log after 1 hour). However, the respiratory activity of $E$. coli cells decreased less, showing only a decline of $0.23-\log$ after 1 hour. During the first 10 minutes of treatment able to divide and metabolically active E. coli cells concentration rapidly decreased and the prolonged low chlorine treatment resulted in an increase. This can be explained as an onset of chlorine stress, but since the chlorine concentration was too low, E. coli could recover.

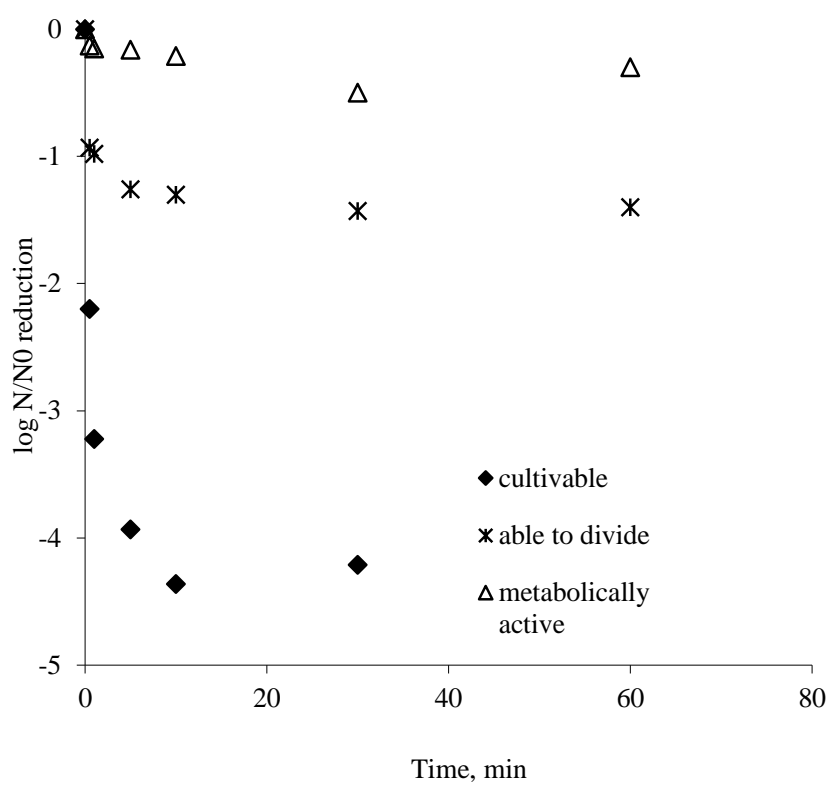

Fig. 2. Effect of $0.1 \mathrm{mg} / \mathrm{L}$ chlorine concentration on inactivation of cultivable $(\bullet)$, able to divide $(\times)$ and metabolically active $(\Delta) E$. coli. The data are the mean of three separate experiments.

For the disinfection at initial chlorine concentration of $0.1 \mathrm{mg} / \mathrm{L} \mathrm{Cl} \mathrm{Cl}_{2}$ (Fig. 2), the highest viable cell counts after 1 hour were observed with the CTC method (only $0.30 \mathrm{log}$ reduction). At the same time, a 2.20-log reduction was observed for cultivable counts within 30 seconds and almost a 5-log reduction after 1 hour. The DVC method showed a $1.40-\mathrm{log}$ reduction in able to divide counts after 1 hour, indicating a rapid decrease in the ability to form colonies but still retaining the capacity for dividing. Similar findings have been described for E. coli cells in chlorinated drinking water [21] and biofilm [22].

Higher initial chlorine concentrations $(0.2 \mathrm{mg} / \mathrm{L}, 0.5 \mathrm{mg} / \mathrm{L}$ and $5 \mathrm{mg} / \mathrm{L} \mathrm{Cl}_{2}$ ) reduced the cultivability of $E$. coli cells for at least 5-log units in 30 seconds. In other words, after 30 seconds of treatment no $E$. coli cells formed colonies on a solid medium. This observation of cultivability loss is in agreement with what has been previously reported for Helicobacter pylori [23] and E. coli [24]. At the same time, only a $0.42-\log$ reduction after 1 hour $\left(0.2 \mathrm{mg} / \mathrm{L} \mathrm{Cl}_{2}\right)$ of treatment was observed for a metabolic activity. To rapidly reduce metabolically active $E$. coli cell concentration, high chlorine concentration $\left(5 \mathrm{mg} / \mathrm{L} \mathrm{Cl}_{2}\right.$ ) was necessary. Only then a 5-log reduction within 1 minute was observed.

At high initial chlorine concentrations $(0.5 \mathrm{mg} / \mathrm{L}$ and $5 \mathrm{mg} / \mathrm{L}$ $\mathrm{Cl}_{2}$ ), the number of able to divide $E$. coli cells decreased to $90 \%$ after 30 seconds. Increasing the contact time to 1 hour did not further increase the inactivation rates, suggesting that DVC method was not efficient in the enumeration of viable (noncultivable) E.coli after chlorination. However, similar observations [22] have been previously explained as a rapid onset of death for cells ongoing division. Thus, the increase in the detection limits of the DVC method to determine low concentration of able to divide cells and use of stationary phase 
cultures could be suggested. Furthermore, the combination of the DVC method with in situ hybridization could be a useful method to simultaneously detect and specifically identify low concentration of viable (able to divide) cells in water and biofilm samples after chlorination [23], [25].

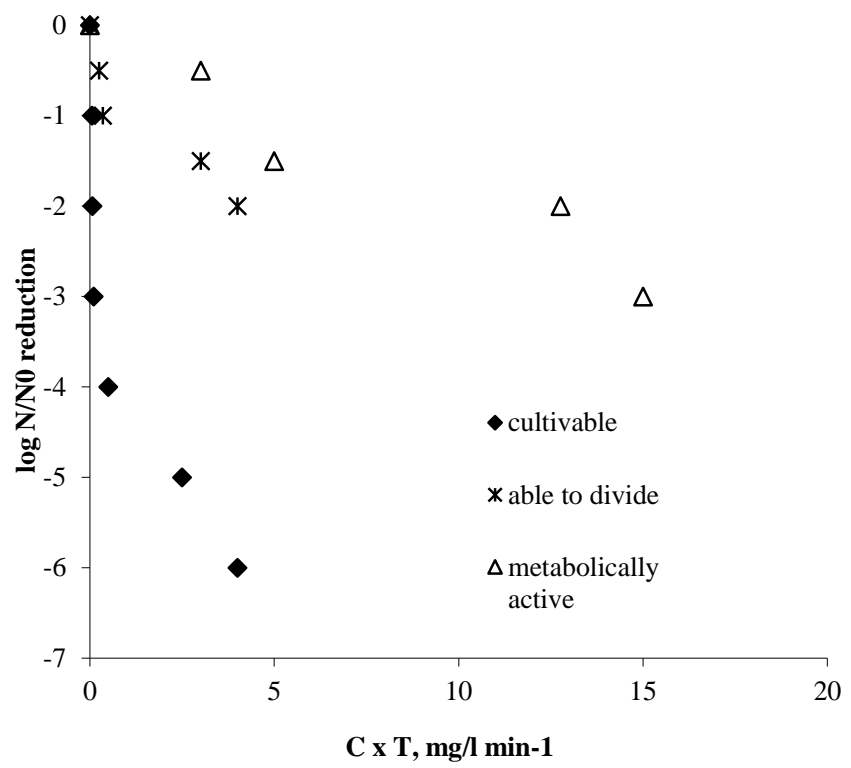

Fig. 3. Relationship between $\log$ survival and CT. Chlorine concentration $(\mathrm{mg} / \mathrm{L})$ and contact time (minutes) required to reduce cultivable $(\diamond)$, able to divide $(\times)$ and metabolically active $(\Delta) E$. coli. The data are the mean of three separate experiments.

The results (Fig. 3) showed that, when chlorinated, E. coli first lost its cultivability giving a low CT value $\left(0.064 \mathrm{mg} / \mathrm{L} \mathrm{min}^{-1}, 99 \%\right.$ inactivation) which was similar to earlier reported for coliforms $\left(0.075 \mathrm{mg} / \mathrm{L} \mathrm{min}^{-1}\right.$ at $\mathrm{pH} 7.0$ and $\left.20^{\circ} \mathrm{C}\right)$ [26] and in the ranges $\left(0.04 \mathrm{mg} / \mathrm{L} \mathrm{min}-1-0.92 \mathrm{mg} / \mathrm{L} \mathrm{min}^{-1}\right)$ of previously reported values for $E$. coli at different temperatures, $\mathrm{pH}$ values and chlorine compounds used [18]. Moreover, the recommended doses $\left(0.08 \mathrm{mg} / \mathrm{L} \mathrm{min}{ }^{-1}\right.$ at $\mathrm{pH} 7.0$ and $\left.1{ }^{\circ} \mathrm{C}-2{ }^{\circ} \mathrm{C}\right)$ for bacterial inactivation were not exceeded [2]. However, to decrease the E. coli ability to divide for $90 \%$, much higher CT values were needed $\left(0.35 \mathrm{mg} / \mathrm{L} \mathrm{min}^{-1}\right)$. Finally, the highest inactivation doses were necessary to neutralize cell metabolic activity $(\mathrm{CT}=$ $12.76 \mathrm{mg} / \mathrm{L} \mathrm{min}{ }^{-1}, 99 \%$ inactivation), indicating higher $E$. coli tolerance limits to chlorine disinfection than considered before.

\section{B. Electrochemical Disinfection}

The application of electrochemical disinfection at chloride ion concentrations similar to drinking water $\left(\sim 35.5 \mathrm{mg} / \mathrm{L} \mathrm{Cl}^{-}\right)$ gave no significant decrease $(p>0.3)$ in cultivable counts after 5 minutes of treatment; however, after 15 minutes a significant decrease $(p<0.05)$ was observed and accounted for more than a 5-log decrease (Fig. 4). This can be explained by a rapid onset of active chlorine formation after 5 minutes of electrolysis. Similar results were reported previously [16] when low chloride ion concentrations (below $7 \mathrm{mg} / \mathrm{L} \mathrm{Cl}^{-}$) were used.

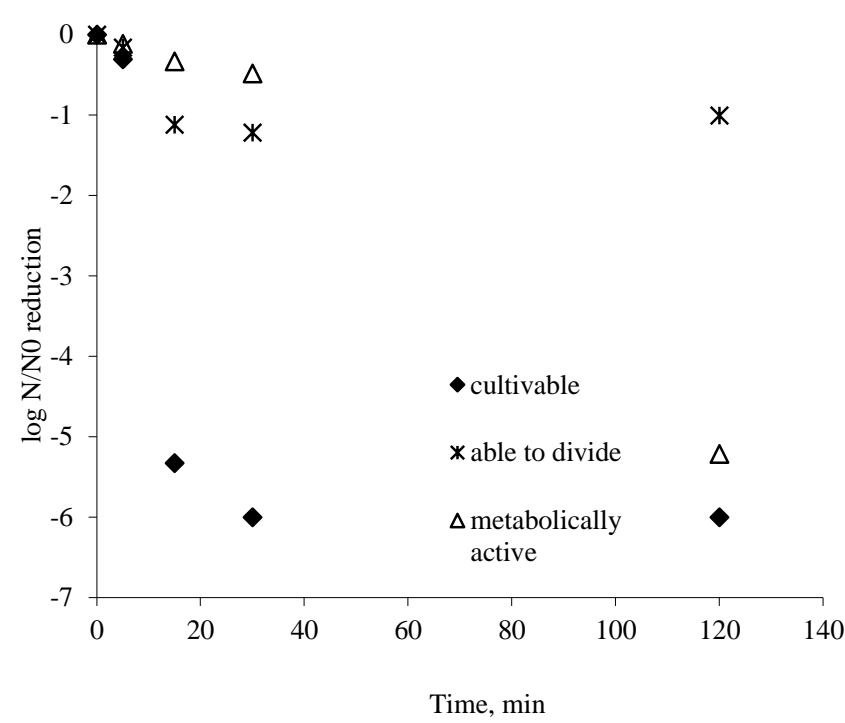

Fig. 4. The effect of electrochemical disinfection $\left(0,1 \mathrm{~A}, 35.5 \mathrm{mg} / \mathrm{L} \mathrm{Cl}^{-1}, \mathrm{RT}\right)$ to reduce cultivable $(\bullet)$, able to divide $(\times)$ and metabolically active $(\Delta)$ $E$. coli with respect to $\mathrm{mg} / \mathrm{L}$ of free available chlorine (black line) generated. The data are the mean of three separate experiments.

No significant decrease $(p>0.3)$ in able to divide cell counts was observed within 5 minutes of treatment with electrolysis, after 15 minutes, similarly as for chlorination studies, only $90 \%$ decrease was obtained $(p<0.05)$. This again could be explained by the limits of the DVC method applied.

As previously reported [16], the decrease in metabolically active cell concentration was the slowest. No significant $(p>0.05)$ decrease in metabolically active cell counts were observed after 1 hour of treatment. However, after 2 hours the amount of metabolically active cells fell below the detection limit, accounted for a significant decrease. Thus, it was possible to demonstrate a full neutralization (no metabolic activity) of E. coli when electrochemical disinfection with no active disinfectant added was used.

\section{DISCUSSION}

The choice of the viability parameters in this study was based on the review of previous studies [21], [25], [27], [28] which described that the respiratory activity (CTC), substrate responsiveness (DVC assay) and cultivability were more direct methods for cell viability.

The results of the study showed that traditional faecal indicator - Escherichia coli which is regarded as very susceptible to chlorination - could survive for much longer periods than it was assumed. The CT values for chlorination and electrochemical treatment time necessary to inactivate metabolically active and able to divide cells were much higher than for the cultivable cells. However, it must be emphasized that the use of elevated chlorine concentrations would be impossible due to the fact that drinking water must be not only microbiologically but also chemically safe and should not exhibit any inappropriate taste and odor.

Although studies have shown that the presence of $E$. coli in drinking water may represent either a true contamination event or can be released in the drinking water from the biofilm [29], 
the application of culture based methods for the estimation of the disinfection efficiency is somewhat overestimated [30]. This observation was supported also in this study, where cultivability showed 5 to 200 times lower CT value than DVC and CTC assays, respectively, which would support the observation that other viability methods should be used in drinking water quality monitoring together with the cultivability.

Finally, although chlorination still remains as one of the most widely used disinfection techniques worldwide, it might be advisable that additional point-of-use water treatment techniques like electrochemical disinfection should be reevaluated and applied in places, where remaining disinfectant concentrations are below critical limits.

\section{ACKNOWLEDGEMENTS}

The present research has been partly supported by the European Regional Development Fund within the project "Development of Innovative Water Procession Technology Using Nanostructured Ceramics"

No. 2010/0257/2DP/2.1.1.1.0/10/APIA/VIAA/012.

\section{REFERENCES}

[1] White, G. C. Handbook of chlorination and alternative disinfectants, New York: John Wiley \& Sons, Inc, USA, 1999, $4^{\text {th }}$ edition,

[2] World Health Organization. Guidelines for drinking-water quality $3^{\text {rd }}$ edition incorporating the first and second addenda/ Geneva: WHO Press, 2008

[3] Linden, K. G., Shin, G. A., Faubert, G., et al. UV disinfection of Giardia lamblia cysts in water. Environmental Science and Technology, 2002, vol. 36, N 11, pp. 2519-2522. http://dx.doi.org/10.1021/es0113403

[4] Shin, G. A., Linden, K. G., Arrowood, M. J., et al. Low - pressure UV inactivation and DNA repair potential Cryptosporidium parvum oocysts. Applied and Environmental Microbiology, 2001, vol. 67, N 7, pp. 3029-3032. http://dx.doi.org/10.1128/AEM.67.7.3029-3032.2001

[5] Environmental Protection Agency. Health Risks from Microbial Growth and Biofilms in Drinking Water Distribution Systems/ EPA, Washington, USA, 2002

[6] Oliver, JD. Recent findings on the viable but nonculturable state in pathogenic bacteria. FEMS Microbiology Reviews, 2010, vol. 34, N 4 pp. $415-425$.

[7] Guo, M., Huang, J., Hu, H., et al. UV inactivation and characteristics after photoreactivation of Escherichia coli with plasmid: health safety concern about UV disinfection. Water Research, 2012, vol. 46, N 13 pp. 4031-4036. http://dx.doi.org/10.1016/j.watres.2012.05.005

[8] Oliver, JD. The viable but nonculturable state in bacteria. The Journal of Microbiology, 2005, vol. 43, pp. 93-100.

[9] Keer, J. T., Birch, L. Molecular methods for the assessment of bacterial viability. Journal of Microbiological Methods, 2003, vol. 53, N 2 pp. 175-183. http://dx.doi.org/10.1016/S0167-7012(03)00025-3

[10] Kogure, K., Simidu, U., Taga, N. A tentative direct microscopic method for counting living marine bacteria. Canadian Journal of Microbiology, 1979, vol. 25, N 3, pp. 415-420. http://dx.doi.org/10.1139/m79-063

[11] Rodríguez, G. G., Phipps, D., Ishiguro, K., et al. Use of a fluorescent redox probe for direct visualization of actively respiring bacteria. Applied and Environmental Microbiology, 1992, vol. 58, N 6, pp. 1801-1808.

[12] Button, D. K., Schut, F., Quang, P., et al. Viability and isolation of marine bacteria by dilution culture: theory, procedures, and initial results. Applied and Environmental Microbiology, 1993, vol. 59, N 9, pp. 881-891.

[13] Servais, P., Agogue, H., Courties, C., et al. Are the actively respiring cells (CTC positive) those responsible for bacterial production in aquatic environment? FEMS Microbiology Ecology, 2011, vol. 35, pp. 171-179. http://dx.doi.org/10.1111/j.1574-6941.2001.tb00801.x

[14] LVS EN ISO 7393-1:200. Water quality - Determination of free chlorine and total chlorine - Part 1: Titrimetric method using N, N-diethyl-1, 4-phenylenediamine/ Riga, Latvia, 2001.
[15] Pavlova, A., Berzina-Cimdina, L., Locs, J., et. al. Preparation and characterization of dense $\mathrm{TiO}_{2}$ ceramics. Advances in Science and Technology, 2008, vol. 54, pp. 261-264. http://dx.doi.org/10.4028/www.scientific.net/AST.54.261

[16] Reimanis, M., Mezule, L., Malers, J., et al. Model water disinfection with electrolysis using $\mathrm{Ti}_{\mathrm{n}} \mathrm{O}_{2 \mathrm{n}-1}$ containing ceramic electrodes. Environmental Biotechnology, 2011, vol. 7, N 1, pp. 34-40.

[17] Ho, L., Onstad, G., Gunten, U., et al. Differences in the chlorine reactivity of four microcystin analogues. Water Research, 2006, vol. 40, N 6, pp. 1200-1209. http://dx.doi.org/10.1016/j.watres.2006.01.030

[18] LeChevallier, M., Cawthon, C., Lee, R. Inactivation of biofilm bacteria. Applied and Environmental Microbiology, 1988, vol. 54, N 10, pp. 2492-2499.

[19] Gunter, U., Driedger, A., Gallard, H., et al. By - products formation during drinking water disinfection: a tool to assess disinfection efficiency? Water Research, 2011, vol. 35, N 8, pp. 2095-2099.

[20] United States Environmental Protection Agency. LT1ESWTR Disinfection Profiling and Benchmarking Technical Guidance Manual, USA, 2003, pp. 93-98.

[21] Tryland, I., Pommepuy, M., Fiksdal, L. Effect of chlorination on $\beta$-Dgalactosidase activity of sewage bacteria and Escherichia coli. Journal of Applied Microbiology, 1998, vol. 85, N 1, pp. 51-60. http://dx.doi.org/10.1046/i.1365-2672.1998.00465.x

[22] Mezule, L. Significance of nonculturable Escherichia coli in drinking water systems. PhD. thesis. Lambert Academic Publishing, 2012.

[23] Moreno, Y., Piqueres, P., Alonso, J. L., et al. Survival and viability of Helicobacter pylori after inoculation into chlorinated drinking water. Water Research, 2007, vol. 41, N 15, pp.3490-3496. http://dx.doi.org/10.1016/j.watres.2007.05.020

[24] Zhao, T., Doyle, M. P., Zang, P., et al. Chlorine inactivation of Escherichia coli O157: H7 in water. Journal of Food Protection, 2001, vol. 64, N 10, pp. 1607-1609.

[25] Joux, F., LeBaron, P. Ecological implications of an improved direct viable count method for aquatic bacteria. Applied and Environmental Microbiology, 1997, vol. 63, N 9, pp. 3643-3647.

[26] Lee, Y., Nam, S. Reflection on kinetic models to the chlorine disinfection for drinking water production. The Journal of Microbiology, 2002, vol. 40, N 2, pp.119-124.

[27] Creach, V., Baudoux, A., Bertru, G., et al. Direct estimate of active bacteria: CTC use and limitation. Journal of Microbiological Methods, 2003, vol. 52, N 1, pp. 19-28. http://dx.doi.org/10.1016/S01677012(02)00128-8

[28] Coallier, J., Prevost, M., Rompre, A., et al. The optimization and application of two direct viable count methods for bacteria in distributed drinking water. Canadian Journal of Microbiology, 1994, vol. 40, pp. 830-836. http://dx.doi.org/10.1139/m94-132

[29] Williams, M. M., Braun-Howland, E. B. Growth of Escherichia coli in model distribution system biofilms exposed to hypochlorous acid or monochloramine. Applied and Environmental Microbiology, 2003, vol. 69, N 9, pp. 5463-5471. http://dx.doi.org/10.1128/AEM.69.9.5463$\underline{5471.2003}$

[30] Yu, F. P., McFeters, G. A. Physiological responses of bacteria in biofilms to disinfection. Applied and Environmental Microbiology, 1994, vol. 60, N 7, pp. 2462-2466.

Viktorija Denisova received B. sc. ing. and M. sc. ing. degrees from Riga Technical University (RTU) in 2011 and 2012, respectively.

In the period of 2009-2012 she was a Laboratory Assistant at the Department of Water Engineering and Technology of Riga Technical University. Since 2013, she has been a Technician of the Faculty of Material Science and Applied Chemistry. Since 2014, she has been a Research Assistant of the Faculty of Civil Engineering.

Research interests: drinking water quality, drinking water treatment. The results of research have been presented in 2 local scientific conferences.

E-mail: viktorija.denisova@rtu.lv

Linda Mezule, Dr. sc. ing, Researcher at Riga Technical University (RTU), Department of Water Engineering and Technology, Institute of Heat, Gas and Water Technology, the Faculty of Civil Engineering.

Main research interests: detection of pathogens in drinking water biofilm using FISH method; development of molecular methods for identification of bacteria. The results of the research have been approbated in more than 10 scientific publications.

E-mail: linda.mezule@rtu.lv 
Talis Juhna, Dr. sc. ing., Professor of Riga Technical University (RTU), Department of Water Engineering and Technology, Institute of Heat, Gas and Water Technology, the Faculty of Civil Engineering.

Since 2012, he has been a Vice-Rector for Research at Riga Technical University.
Main research interests: drinking water treatment; removal of natural organic matter; iron and manganese removal from groundwater; bacterial growth in water distribution networks; rapid methods for identification of pathogens in drinking water. T. Juhna is the author of more than 100 scientific publications. E-mail: talis.juhna@rtu.lv

\section{Viktorija Deņisova, Linda Mežule, Tālis Juhna. Hlorēšanas ietekme uz Escherichia coli dzīvotspēju dzeramā ūdenī.}

Dzeramā ūdens hlorēšana ir viena no visbiežāk pielietotajām dezinfekcijas metodēm attīstītajās valstīs. Dzeramā ūdens kvalitātes un dezinfekcijas efektivitātes novērtēšanai nosaka fekālā piesārņojuma indikatororganismu, galvenokārt, Escherichia coli, klātbūtni sagatavotajā ūden̄̄. Dezinfekcijas efektivitātes aprēkināšanai izmanto mikroorganismu spēju vairoties mikrobiologiskās barotnēs (kultivēšanas metode), tomēr zināms, ka oligotrofā vidē daudzi mikroorganismi, t.sk. E. coli var būt sastopami dzīvotspējīgā, bet nekultivējamā stāvoklī. Pētījuma mērkis bija noteikt dezinfekcijas efektivitāti ne tikai ar tradicionāli pielietotu metodi, bet arī ar citām E. coli fiziologíiskā stāvokḷa novērtēšanas molekulārajām metodēm. Darba ietvaros tika analizēta $E$. coli šūnu spēja veidot kolonijas, dalīšanas potenciāls, kā arī E. coli metaboliskā aktivitāte. Eksperimentu norises laikā tika novērots, ka vispirms samazinās E. coli kultivējamība, pēc tam dalīšanās potenciāls un tikai tad samazinās $E$. coli šūnu metaboliskā aktivitāte, tāpēc kultivēšanas metodes pielietojums hlorēšanas efektivitātes novērtēšanā netiek uzskatāms par pietiekoši reprezentatīvu. Pētījumu rezultātā tika noskaidrots, ka, lai neitralizētu 99 \% kultivējamo E. coli, nepieciešami $0,064 \mathrm{mg} / \mathrm{L} \mathrm{min}{ }^{-1}$ hlora. Taču, lai samazinātu dalīties spējīgo un metaboliski aktīvo E. coli šūnu koncentrāciju, bija nepieciešama attiecīgi 5 līdz 200 reizes lielāka dezinfekcijas deva reizkontaktlaiks. Rezultāti parādīja, ka pareizai dzeramā ūdens dezinfekcijas devas noteikšanai nepieciešams izvērtēt vairākus šūnu dzīvotspējas rādītājus.

\section{Виктория Денисова, Линда Межуле, Талис Юхна. Влияние хлорирования на жизнедеятельность Escherichia coli в питьевой} воде.

Хлорирование воды - наиболее распространенный способ обеззараживания питьевой воды. Индикатором качества питьевой воды и эффективности процесса дезинфекции является наличие фекального загрязнения, в основном Escherichia coli, в воде. Традиционно для оценки эффективности дезинфекции используется поверхностный метод для культивирования микроорганизмов. Однако известно, что многие микроорганизмы, в том числе и $E$. coli, в олиготрофных условиях могут быть жизнеспособными, но некультивированными, т.е. не образующими колонии на твёрдых питательных средах. Цель исследования заключалась в определении эффективности дезинфекции не только традиционным методом, но и другими молекулярными методами для изучения физиологических свойств E. coli. В ходе работы были проанализированы колониеобразующие свойства клеток E. coli, их способность делиться, а также их метаболическая активность. В результате нашего исследования эффективность хлорирования воды для удаления 99 \% культивированных клеток $E$. coli составила $0.064 \mathrm{mg} / \mathrm{L} \mathrm{min}^{-1}$. Однако, чтобы уменьшить способность $E$. coli клеток к делению и метаболическую активность, было необходимо увеличить отношение дозы дезинфектанта ко времени (доза х время) от 5 до 200 раз соответственно. Другими словами, сначала уменьшаются колониеобразующие свойства клеток $E$. coli, потом их способность делиться, и только затем уменьшается их метаболическая активность. Результаты показали, что для определения правильной дозы дезинфектанта для обеззараживания питьевой воды необходимо анализировать несколько параметров жизнеспособности микроорганизмов. 